\title{
Využití gymnastiky v suché prípravě hokejistů
}

\section{Utilization of gymnastics in the dry preparation of hockey players}

\author{
Jaroslav Krištofič, Martin Humler \\ Fakulta tělesné výchovy a sportu Univerzity Karlovy v Praze
}

\begin{abstract}
Abstrakt
Ledníhokej a gymnastika jsou dva rozdílné sporty se specifickým obsahem a specifickými motorickými nároky. Přes tyto rozdílnosti mohou být gymnastická průpravná cvičení vhodným doplňkem suché prípravy hokejistů prováděné mimo ledovou plochu. Gymnastická průpravná cvičení jsou charakteristická společnou stimulací kondičních a koordinačních pohybových funkcí s pozitivním dopadem na výkonné i řídicí složky. Rozvíjejí způsobilost koordinovat pohyb tělesných segmentů v prostoru a čase, kinestetickou citlivost a diferenciaci. Kromè toho přináší zařazování gymnastických průprav i kompenzační efekt vůči jednostranné zátěži s pozitivním dopadem v oblasti zdravotní prevence. Výsledky dotazníkového šetření mezi trenéry ledního hokeje mládežnických kategorií (11-17 let) vykazují výraznou podporu zařazování těchto aktivit v rámci suché prípravy. Z oslovených trenérů $74 \%$ uvedlo, že gymnastické průpravy jsou pravidelnou součástí sportovní prípravy jejich týmů a $25 \%$ je zařazuje nepravidelně. Na dotaz, jestli považuji tento druh suché prípravy za účelný a má jejich podporu (bez ohledu na to, jestli jej zařazuji) odpovědělo 81 \% určitě ano, 19\% spiše ano a nikdo z oslovených respondentů se nevyjádřil negativně.
\end{abstract}

\begin{abstract}
:
Ice hockey and gymnastics are two different sports with the specific content and specific motor abilities claims. In spite of these differences can be gymnastic preparation a good complement to the dry preparation carried out-off ice rink. Gymnastic exercises are based on joint stimulation of fitness functions and coordination functions with a positive impact on the performance and control folder. They develop the capacity to coordinate the movement of body segments in space, kinestetic sensitivity and differentiation. In addition, the gymnastic preparations brings a compensatory effect against unilateral load with a positive impact in the area of health prevention. The results of a questionnaire survey among the coaches ice hockey of youth category (11-17 years) reported strong support of the inclusion gymnastic activities in dry preparation. From the polled coaches $74 \%$ said that gymnastic preparations are a regular part of sports training their teams and $25 \%$ indicated posibility "irregularly". When asked if they consider this kind of dry preparation for efficient and support of them (regardless if they do it) $81 \%$ responded definitely Yes, $19 \%$ rather Yes, and noone of the polled respondents reported No, or rather No.
\end{abstract}

Klíčová slova: gymnastické průpravy, motoricko-funkční príprava, posilování svalů tělesného jádra, kompenzační cvičení.

Key words: gymnastic preparation, motor-functional training, core strength training, compensatory exercises. 


\section{ÚVOD}

Lední hokej patří mezi nejrozššřenější sporty v České republice a dle údajů Českého svazu ledního hokeje (www.cslh.cz) je v současnosti registrováno cca 110000 hráčủ všech věkových kategorií včetně žen. Z toho je cca 85000 hráčů seniorských kategorií a podle IIHF jsme z tohoto hlediska třetí největší velmocí na světě. V České republice je 150 krytých hřišt', na kterých může probíhat systematicky trénink ledního hokeje, což vzhledem k uvedeným počtům registrovaných hráčủ a jiným důvodům (např. finanční náročnost) nedává všem klubům možnost strávit na ledové ploše časové penzum dle jejich představ a je to důvodem $\mathrm{k}$ hledání alternativních řešení. Jedním $\mathrm{z}$ těchto doplňkových řešení je tzv. suchá př́íprava, která rozšiřuje tréninkový proces o pohybové aktivity i mimo ledovou plochu a představuje účelné navýšení tréninkového objemu. Pro lední hokej je typická široká škála pohybů, at už se jedná o různé prvky bruslení nebo o práci s hokejovou holí. Hráč musí zvládat techniku bruslení v jejích jednotlivostech, rychlou změnu směru pohybu, srážky a boj o kotouč s protihráči, nájezdy do volných prostor hřiště v rámci taktických variant apod. Hokej je sice kolektivním sportem, avšak každý hráč podává při utkání individuální výkon, který je pak spojován taktickou prŕípravou celého mužstva (Kostka, Bukač \& Šafařík, 1986). V rámci komplexní sportovní prrípravy, především pak u mládeže, by měl být brán zřetel na pestrost a různorodost pohybů ve smyslu pohybové všestrannosti (Perič \& Dovalil, 2010).

Bukač (2005) vymezuje ve své práci pojem „kondiční a herně rozvíjející trénink“ (KRT) a uvádí, že jeho část probíhající na ledě se často prolíná s tréninkem herně dovednostního základu (HDZ) a jsou pro něj typická různá celohřištová herní cvičení vysoké intenzity. Druhou část KRT prováděnou mimo led pak nazývá suchou přípravou, ve které je kladen důraz především na nárůst síly, dynamičnosti, silové obratnosti a agility. K tomu se využivají gymnastická průpravná cvičení na rozvoj silové obratnosti, průpravná cvičení na rytmizaci řetězících se pohybů (změny směru pohybu, starty a zastavení, obraty, rychlé změny poloh, apod.) a sportovní hry. Dalším cílem tréninku mimo led je podle autora nárůst kondiční perzistence na dynamickou zátěž. Pro tento účel doporučuje využívat aerobně silový trénink intervalového nebo celostního charakteru. Suchou prrípravu doporučuje zařazovat $\mathrm{v}$ přípravném a předzávodním období především u mladých hráčủ do 25 let. U starších hráčů se pak jedná spiše o kondičně udržovací trénink, protože jsou fyzicky ustálenější a jejich kondiční kapacita je vyhraněná a stabilizovaná. Přípravné a předzávodní období je podle Periče (2002) zaměřeno na rozvoj určujících pohybových schopností a formování širokého spektra pohybových dovedností. V tomto kontextu lze očekávat největší přínos suché prrípravy právě zde. Pavliš et al. (2003) doporučují do aktivit mimo led zařazovat především cvičení na rozvoj specifické rychlosti, síly, vytrvalosti, silové vytrvalosti a koordinace.

Účelem gymnastických průprav zařazovaných $\mathrm{v}$ rámci sportovní př́pravy $\mathrm{v}$ jiných sportech není osvojit si specifické gymnastické cviky, ale stimulovat percepční a motorické funkce ve smyslu vnímání pohybu tělesných segmentů v koordinačních souvislostech, ve způsobilosti „unést se“ a pozitivně ovlivňovat statickou i dynamickou posturální stabilitu. Silovou obratnost, která je pro tyto činnosti charakteristická, definoval Kuzněcov (1974) jako schopnost přesně diferencovat úsilí různého charakteru při různém pracovním režimu svalů a v rámci přesně vymezených pohybů, jinými slovy naučit se efektivně využívat energetický potenciál, časově a prostorově koordinovat účinky silových impulsů a vynakládat jen tolik síly, kolik je ke splnění pohybového úkolu nutné. Všestranná pohybová př́iprava je $\mathrm{v}$ gymnastických sportech naplňována tzv. motoricko-funkční přípravou, kterou lze definovat jako systém dílčích pohybových příprav, jejichž prostřednictvím jsou vytvářeny a formovány vnitřní předpoklady pro efektivní osvojování pohybových dovedností účelnou technikou a bez zdravotních rizik (Krištofič, 2014). Motoricko-funkční př́íprava propojuje kondiční a technickou složku sportovního tréninku a vytváŕí základ pohybových návyků, které jsou později využívány v procesu motorického učení. Mezi základní bloky motoricko-funkční přípravy 
patří zpevňovací příprava, podporová příprava, rotační příprava, odrazová a doskoková příprava, visová př́iprava, stimulace reaktibility, silové obratnosti, rytmických schopností a flexibility (Krištofič, 2004). Ve sportovní přípravě ledních hokejistů v rámci suché přípravy se jeví jako účelné zařazovat zpevňovací a rotační přípravu, stimulaci reaktibility, silové obratnosti a z kompenzačních důvodů také stimulovat flexibilitu.

Zpevňovací príprava - jejím cílem je rozvoj způsobilosti udržet tělo zpevněné v daných polohách a pohybech, kdy musí jedinec svalovou aktivitou zamezit nežádoucím souhybům mezi jednotlivými tělesnými segmenty. Důraz je kladen na stabilizaci výškové osy těla zpevněním svalů tělesného jádra, respektive hlubokého stabilizačního systému, jak ve stabilních, tak v labilních polohách. Tato „zpevňovací funkce“ vždy byla a je v rámci gymnastických průprav dominantní s velkým přesahem i mimo gymnastické sporty. $Z$ jejích principů vychází dnes velmi populární „core training“ zaměřený na posilování svalů tělesného jádra ve smyslu posilování funkční stability tohoto tělesného segmentu jako celku, což je rozdílné od posilování jednotlivých svalů a významně ovlivňuje statickou i dynamickou posturální stabilitu (zpevňovací př́ípravu a „core training“ lze zjednodušeně vnímat jako synonyma). Bukač (2005) uvádí, že nastavená ohrožení dynamické rovnováhy specificky koaktivují opěrnou motoriku a akutní úkon je tak dynamicky stabilizován. „Core training“" považuje za praktickou realizaci agility v tréninku zaměřenou na uzlové balanční body. Jebavý \& Zumr (2009) charakterizují „core training“ jako posilování tělesného jádra, jehož principem je zpevnění, respektive aktivace určitých svalů nebo svalových skupin, což vede ke stabilizaci axiálního systému. Tím je pak umožněno vyvinutí větší síly na periferiích a zlepšuje se tak ekonomika pohybu. Podle Handzela (2013) je tělesné jádro „hnacím motorem“ a „centrem síly“, které „vstupuje do hry“ při veškerých pohybech.

Stimulace reaktibility - tak označujeme rozvoj způsobilosti rychle a adekvátně reagovat na určitý podnět (akustický, vizuální, taktilní). Rychlost reakce ovlivňují tři aspekty - vnímání situace, její vyhodnocení a způsobilost provést rychle pohybový úkon. Podle Schmidta \& Wrisberga (2008) je indikátorem rychlosti a efektivnosti lidského rozhodování reakční doba. Cílem rozvoje reaktibility je ovlivňování způsobilosti co nejrychleji provádět pohybové úkoly obratnostního charakteru, tedy nejen rychle, ale i technicky korektně, což může být označeno jako „koordinace pod tlakem“. V rámci suché přípravy hokejistů může být příkladem podbíhání otáčejícího se dlouhého švihadla při současném vedení tenisového míčku nebo puku hokejovou holí. Hráč musí vnímat polohu švihadla, protože pouze v jediné fázi a pod časovým tlakem lze provést pohybový úkol.

Stimulace silové obratnosti - tyto činnosti se zaměřují především na posilování s vlastní tělesnou hmotností, kdy je přechod z výchozí do výsledné polohy spojen jak s kondičními, tak koordinačními nároky ve smyslu přesnosti průběhu pohybu, přesného načasování jednotlivých akcí, vyvažování labilní polohy apod. Na rozdíl od klasického posilování, kdy ke ztížení cvičení dochází nejčastěji navyšováním váhy na čince, zde zobtížňujeme cvičení zvýšením koordinační náročnosti (nestabilní povrch, zavřené oči apod.). V rámci stimulace silové obratnosti se využívají různá náčiní a nářadí jako gymnastické kruhy, TRX, Bosu, balanční podložky apod.

Rotační príprava - jejím cílem je především rozvoj orientace v prostoru (stimulace centrálního i periferního vidění $\mathrm{v}$ různých polohách a pohybech, stimulace funkcí vestibulárního aparátu apod.), rozvoj způsobilosti roztáčet tělo a účelně regulovat jeho otáčivý pohyb kolem různých os otáčení (výšková osa, předo-zadní osa a pravo-levá osa). Dalším důležitým úkolem rotační př́ípravy je zvládnutí pádových technik (Krištofič, 2006). Nejvhodnějším prostředkem je v tomto ohledu trampolína s měkkou dopadovou žíněnkou. Trampolína umožňuje dostat se po odrazu do letové fáze dostatečného rozsahu a měkká žíněnka umožňuje bezpečně ztlumit dopad např́íklad do kotoulu. Při opakování těchto činností se u cvičenců vytvářejí reflexy, které se ukládají v motorické paměti a následně se podvědomě vybavují v aktuálních situacích podobného charakteru. Naplňuje se tak jejich protiúrazový preventivní význam. 
Zmíněné gymnastické průpravy nejsou izolované, ale vzájemně se překrývají, doplňují a vytvářejí pohybový program, který je aplikovatelný v různých podobách ve venkovním i vnitřním prostředí bez vysokých nároků na materiální vybavení. Cílem tohoto př́íspěvku je profilovat typy průpravných cvičení z oblasti gymnastické motoricko-funkční př́ípravy, které by bylo vhodné použít $\mathrm{v}$ rámci suché prrípravy hokejistů, a na základě dotazníkového šetření mezi trenéry zjistit, jaký je o tento způsob doplňkové sportovní přípravy hokejistů zájem.

\section{METODIKA}

Největší účinek gymnastických průpravných cvičení lze předpokládat u mládežnických kategorií (Bukač, 2005; Krištofič, 2006). Proto jsme se v rámci dotazníkového šetření, které je hlavním výstupem tohoto př́íspěvku, zaměřili na trenéry pečující o mládež ve věkovém rozpětí 11-17 let bez dalšího dělení do dílčích kategorií. Dotazníkového šetření se zúčastnilo celkem 104 trenérů ledního hokeje, frekventantů trenérské školy na FTVS UK. Z tohoto počtu je 92 respondentů trenéry mládežnických kategorií do 17 let a výsledky prezentované v této práci se vztahují pouze $\mathrm{k}$ této kategorii. Nízký počet trenérů vyšších věkových kategorií v rámci tohoto dotazníkového šetření neumožnil porovnání výsledků mezi kategoriemi do 17 let a vyššími na dostatečné úrovni statistické významnosti, a proto zde není tato komparace uváděna. Dotazníkové šetření bylo anonymní s většinou uzavřených otázek, které se zaměřovaly jednak na celkové tréninkové zatížení, ale především na četnost zařazování gymnastických průprav do tréninkového procesu a na názory trenérů na tuto problematiku. $\mathrm{V}$ prezentovaných výsledcích jsou pouze odpovědi na vybrané otázky dotazníku s vazbou na využití gymnastických průprav v tréninkovém procesu hráčủ ledního hokeje a neodrážejí celou šíri dotazníku. Data získaná dotazníkovým šetřením byla vyhodnocena pomocí standardních statistických parametrů a k jejich počítačovému zpracování byl použit program Microsoft Excel.

\section{VÝSLEDKY}

\section{Kolik tréninků (týdně - průměr v sezoně) se odehrává na ledě a kolik mimo něj?}

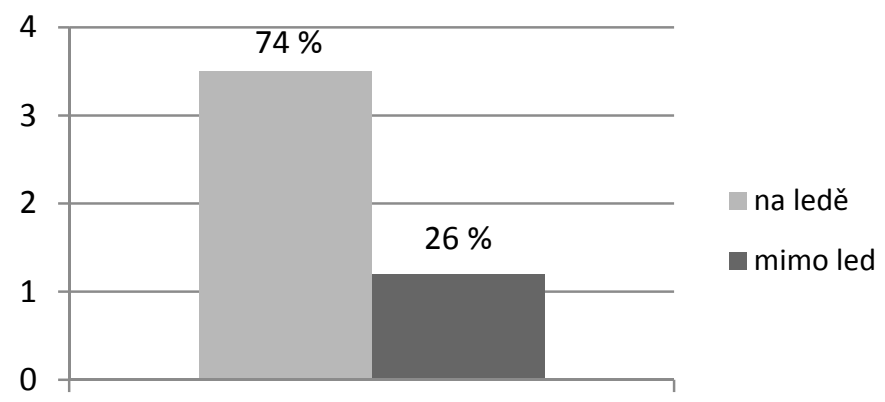

Obr. 1 Poměr tréninků na ledě a mimo led v týdenním cyklu

Z výsledků zde neuváděných otázek $\mathrm{z}$ dotazníkového šetření ohledně průměrného počtu tréninků vyšel údaj 4,5 jednofázových tréninků za týden. U mládežnických kategorií nebývá kromě soustředění dvoufázový trénink součástí běžného režimu, což potvrzuje údaj 0,3 dvoufázových tréninků za týden. Z celkového počtu tréninkových jednotek za týden je jich průměrně $3,5(74 \%)$ realizováno na ledě (viz graf 1) a 1,2 (26\%) mimo led. V aktivitách mimo led není specifikováno, 
v jakém prostředí jsou prováděny (tělocvična, venkovní prostředí, zázemí stadionu) ani o jakou činnost se jedná (běh v prrilehlém okolí, gymnastika v tělocvičně apod.).

2. Zařazujete $v$ rámci suché př́pravy (mimo led) některá gymnastická cvičení (core training, balanční cvičení a jiná obratnostní cvičení)?

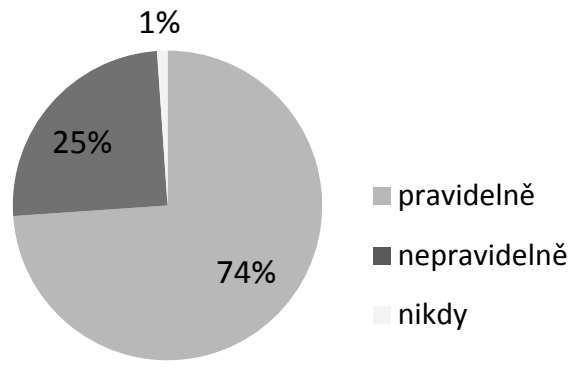

Obr. 2 Zařazování gymnastiky v rámci suché př́pravy

Gymnastické aktivity byly v otázce pouze naznačeny, ale bliže nespecifikovány, aby nevznikl mylný dojem, že je jejich provádění vázáno pouze na prostředí tělocvičny s gymnastickým vybavením a vnímání gymnastiky nebylo redukováno na akrobatické cviky typu kotouly a salta. Z celkové sumy 104 dotázaných trenérů ( 92 trenérů mládeže a 12 seniorských kategorií) pouze dva uvedli, že nikdy v rámci suché přípravy gymnastiku nevyužívají (jeden trenér mládeže a jeden seniorské kategorie), většina trenérů mládeže zařazuje gymnastická cvičení pravidelně (74\%) a 25 \% je zařazuje nepravidelně. Procentuálně z oslovených respondentů cca pouhé jedno procento trenérů mládeže nezařazuje gymnastické průpravy vůbec.

3. Myslíte si, že je zařazování gymnastických průprav do tréninku mladých hokejistů účelné a podporujete tento př́stup?

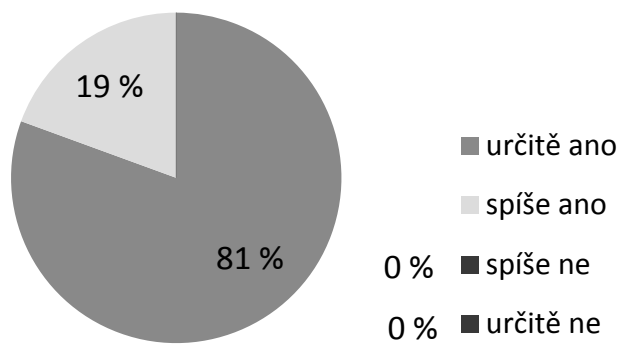

Obr. 3 Podpora zařazování gymnastiky v rámci suché prípravy

V předchozí otázce byli respondenti dotazováni na reálný stav, s jakou pravidelností zařazují gymnastické průpravy do tréninkového procesu. Překážkou jim mohou být časové, prostorové a jiné důvody, a proto se v této otázce ptáme na názor respondentů $\mathrm{z}$ hlediska smysluplnosti a účelnosti zařazování gymnastických průprav v rámci suché přípravy hokejistů (jestli by tak z vlastní vůle činili). Z grafu 3 je patrné, že se naprostá většina respondentů ( $81 \%$ ) ztotožňuje s tímto přístupem, 19 \% vyjadřuje svůj postoj jako „spiše ano“ a žádný z respondentů tento př́stup nezavrhl, ani jej neoznačil jako „spíše ne“. 


\section{Zařazujete do tréninků v rámci suché prípravy kompenzační cvičení?}

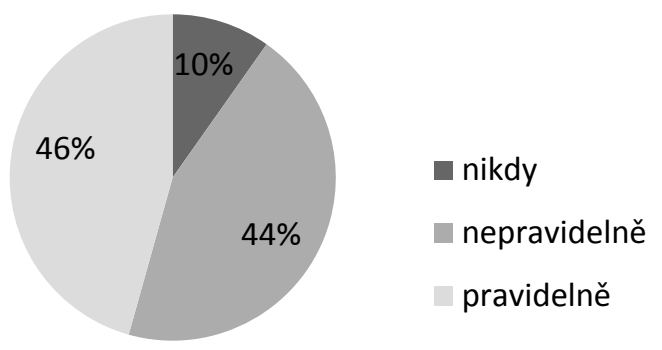

Obr. 4 Zařazování kompenzačních cvičení v rámci tréninku

Z grafu č. 4 je patrné, že $10 \%$ trenérů mládeže nikdy kompenzační cvičení v rámci suché př́ípravy nezařazuje, ze zbylých devadesáti procent $46 \%$ trenérů zařazuje kompenzační cvičení pravidelně a $44 \%$ nepravidelně. Otázka byla položena v obecné rovině bez specifikace konkrétní pohybové činnosti, místa kde je prováděna (v tělocvičně nebo v šatně, venku) a četnosti jejich aplikace.

\section{Zařazujete do tréninku v úvodní nebo závěrečné části statický strečink (výdrže $5 \mathrm{~s}$ a více)?}

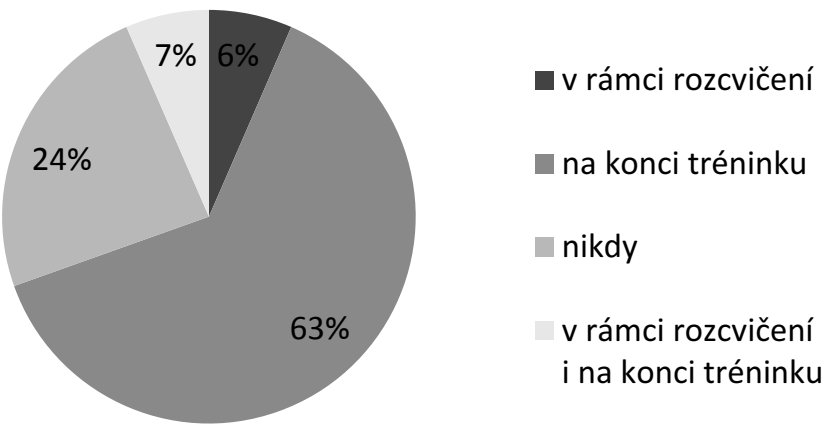

Obr. 5 Zařazování statického strečinku v rámci tréninku

Tato otázka měla podobně jako předchozí dané možnosti odpovědí - ano, v rámci rozcvičení; ano, na konci tréninku; ne, nikdy. S současně bylo možné označit první i druhou variantu (jak v rámci rozcvičení, tak na konci tréninku). Z výsledků uvedených v grafu č. 5 je zřejmé, že nadpoloviční většina $(63 \%)$ trenérů mládeže zařazuje statický strečink pouze na konci tréninku a jen $6 \%$ uvedlo, že tento typ strečinku provádí se svými svěřenci v rámci rozcvičení. Dalších $7 \%$ trenérů zařazuje statický strečink jak v rámci rozcvičení, tak na konci tréninku, a $24 \%$ trenérů statický strečink nezařazuje vůbec.

\section{DISKUSE}

Struktura sportovního výkonu hokejisty je v teoretické rovině rozpracována a popsána (Bukač \& Dovalil, 1990; Bukač, 2005; Kostka, Bukač \& Šafařík, 1986), ale tato struktura má své okolí a je jím ovlivňována. Toto okolí představují i gymnastické průpravy v rámci suché přípravy hráčů ledního hokeje, které nemají přimý vliv na individuální hráčské dovednosti, ani na souhru v rámci taktických variant, ale spoluvytvářejí prostředí pro optimální účinnost nosné struktury. Aby byl sportovec výkonný v dlouhodobé perspektivě, musí být především zdravý. V tomto kontextu 
není nevýznamný ani kompenzační efekt suché přípravy, která by měla zahrnovat i jiné než úzce specializované hokejové činnosti a napomáhat předcházení negativního vlivu jednostranného tělesného zatížení. Pro hráče ledního hokeje je charakteristický stereotyp herního postoje, při kterém je systém posturálního svalstva namáhán atypicky nerovnoměrně, což může být přičinou vzniku svalových dysbalancí. Dochází ke zkrácení posturálně opěrných svalů, k ochabování břišního svalstva, vyklenutí páteře projevující se zvětšenou bederní lordózou a současně ke zkrácení kyčelních ohybačů a bederních vzpřimovačů. Tyto dysbalance ve svém důsledku ovlivňují jednotlivé posturální funkce, respektive kloubní pohyblivost mezi jednotlivými tělesnými segmenty, někdy označovanou termínem ohebnost (Perič \& Dovalil, 2010). Protahovací cvičení mohou být aplikována jako specifická kompenzačních cvičení nebo jako součást bloku gymnastiky, pro kterou je rozvoj flexibility jednou $\mathrm{z}$ priorit. $\mathrm{V}$ posledních letech se výrazně změnil přístup jednotlivých sportovních odvětví $\mathrm{k}$ aplikaci statického strečinku, a to především v rámci rozcvičení. Přes výhrady mnoha odborníků, kteří nedoporučují výdrže v protažení v rámci rozcvičení (McMillian, Moore, Hatler \& Taylor, 2006; Knudson, 2006), není v této oblasti jednoznačná názorová shoda, ale v praxi je patrná významná redukce zařazování statického strečinku do rozcvičení, a naopak nárůst jeho aplikace na konci tréninkové jednotky (Borges Bastos et al., 2013). Tento trend je patrný i z odpovědí na pátou otázku, kdy $63 \%$ respondentů uvedlo, že zařazují statický strečink pouze na konci tréninkové jednotky, $6 \%$ pouze v rozcvičení, $7 \%$ v rozcvičení i na konci tréninku a překvapivě $24 \%$ trenérů nezařazuje statický strečink vůbec. V odpovědi na otázku č. 2 uvedlo $74 \%$ respondentů, že zařazují gymnastické průpravy pravidelně, a $25 \%$ nepravidelně. V jinak položené otázce na stejné téma $81 \%$ respondentů jednoznačně podpořilo tento způsob př́ípravy a 19 \% označilo možnost „spíše ano“, což svědčí o významné podpoře tohoto přístupu, který však není z různých důvodů (priority př́ípravy, časové faktory, materiální podmínky) i v př́ipadě podpory vždy v praxi realizován.

\section{ZÁVĚR}

Stimulace pohybových funkcí, ve kterých jsou současně uplatňovány kondiční i koordinační nároky, napomáhá v rozvoji způsobilosti vnímat své tělo a účelně regulovat pohyb jeho segmentů v prostoru a čase. V rámci gymnastického posilování není prioritou zvyšovat obtížnost pohybového úkolu navýšením zátěže v její absolutní hodnotě, ale zvýšením koordinační náročnosti. Posilování s vlastní tělesnou hmotností stimuluje kinestetickou citlivost a diferenciaci. Gymnastické průpravy v rámci suché př́ipravy hokejistů mimo led přinášejí rozšíření spektra pohybových kompetencí hráčů a současně plní funkci kompenzace jednostranné pohybové zátěže. Jejich realizace není vázaná na speciálně vybavené tělocvičny a většinu z nich lze aplikovat i ve venkovním prostředí. Kladný ohlas trenérské veřejnosti vypovídá o smysluplnosti tohoto př́stupu, respektive o účelnosti zařazování gymnastických průprav v rámci suché přípravy hokejistů, především u mládežnických kategorií.

\section{Literatura}

BORGES BASTOS, C. L., MIRANDA, H., VALE, R. G. S., PORTAL, M. D. N., GOMES, T. M., NOVAES, J. S. \& WINCHESTER, J. B. (2013). Chronic effect of static stretching on strength performance and basal serum IGF-1 levels. Journal of Strength and Conditioning Research, 27, 2465-2472.

BUKAČ, L. (2005). Intelekt, učení, dovednosti \& koučování v ledním hokeji. Praha: Olympia. BUKAČ, L. \& DOVALIL, J. (1990). Lední hokej: trénink herní dokonalosti. Praha: Olympia. HANDZEL, T. M. (2003). Core training for improved performance. NSCA's Performance Training Journal, 2(6), 26-30. JEBAVÝ, R. \& ZUMR, T. (2009). Posilovánís balančními pomůckami. Praha: Grada Publishing. KOSTKA, V., BUKAČ, L. \& ŠAFAŘíK, V. (1986). Lední hokej: teorie a didaktika. Praha: Státní pedagogické nakladatelství. 
KRIŠTOFIČ, J. (2004). Gymnastická průprava sportovce. Praha: Grada Publishing.

KRIŠTOFIČ, J. (2006). Pohybová príprava dětí. Praha: Grada Publishing.

KRIŠTOFIČ, J. (2014). Gymnastické posilování: motoricko-funkční príprava. Praha: Univerzita Karlova, Fakulta tělesné výchovy a sportu.

KNUDSON, D. (2006). The biomechanics of stretching. Journal of Exercise Science \& Physiotherapy, 2, 3-12.

KUZNĚCOV, V. (1974). Silový trénink. Praha: Olympia.

MCMILLIAN, D. J., MOORE, J. H., HATLER, B. S. \& TAYLOR, D. C. (2006). Dynamic versus static-stretching warm up: The effect on power and agility performance. Journal of Strength and Conditioning Research, 20, 492-499.

PAVLIŠ, Z., PERIČ, T., HELLER, J., JANÁK, V., JANSA, P. \& ČASLAVOVÁ, E. (2003). Školení trenérů ledního hokeje. Praha: ČSLH. PERIČ, T. (2002). Lední hokej - trénink budoucích hvězd. Praha: Grada Publishing.

PERIČ, T. \& DOVALIL, J. (2010). Sportovní trénink. Praha: Grada Publishing.

SCHMIDT, R. A. \& WRISBERG, C. A. (2008). Motor learning and performance: a situation-based learning approach. 4th ed. Champaign, IL: Human Kinetics.

\section{Korespondující autor:}

PhDr. Jaroslav Krištofič, jkristofic@ftvs.cuni.cz

Fakulta tělesné výchovy a sportu Univerzity Karlovy

José Martího 269/31

16252 Praha 6 - Veleslavín

Česka republika 